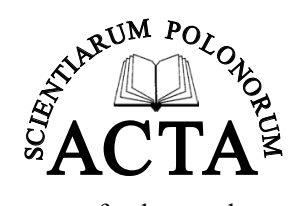

www.food.actapol.net

\title{
NATURAL ANTIOXIDANT EXTRACTS AS FOOD PRESERVATIVES
}

\author{
Norma F. Santos-Sánchez, Raúl Salas-Coronado ${ }^{凶}$, Rogelio Valadez-Blanco, \\ Beatriz Hernández-Carlos, Paula C. Guadarrama-Mendoza \\ Institute of Agroindustries, Technological University of the Mixteca \\ Carretera a Acatlima, km 2.5 Huajuapan de León, CP 69000, Mexico
}

\begin{abstract}
The food industry is becoming more specialized and processing methods are continuously being developed to meet consumer needs. Consumers demand products that are safe and preferably free of synthetic additives. These additives are associated with health effects, in most cases without reasonable justification. Consequently, consumers are looking for clearly labelled products that guarantee the absence of synthetic additives. This has led to the need to search for natural additives, which the food industry claims arenatural antioxidant preservatives. The sources of natural antioxidants can be extremely varied, because practically all plants contain antioxidants that allow them to protect themselves from solar radiation and pests, as well as to regulate the production of chemical energy. However, the best alternatives for the food industry are fruits and spices, because they are already foods themselves. This article will describe fruits and spices considered as important sources of phenolic antioxidants. The main medicinal properties are related to phenolic compounds and their uses as additives, depending on their chemical structure.
\end{abstract}

Keywords: food preservation, natural antioxidants, phenolic extracts of fruits and spices, chemical structure of phenolic compounds

\section{FOOD ADDITIVES}

Food additives are used to facilitate or complement a wide variety of food production methods. The two basic functions of additives are: (1) to make food safe by preserving it from bacteria, as well as to prevent its oxidation and other undesirable chemical changes, and (2) to make food look good and to be palatable. According to the general rule for food additives CODEX-STAN 192-1995, food additives are defined as any substance that by itself is not normally consumed as food and is not used as a characteristic ingredient of food. The result of incorporating an additive into food is that it becomes directly or indirectly a component of the food (Saltmarsh, 2013). Food additives are divided into six groups: 1) preservative, 2) nutritional, 3) coloring, 4) flavoring, 5) texturizing, and 6) miscellaneous. Preservative additives, the subject of this article, are probably the most important class of additives, as they play an important role in the supply of safe food. Preservative additives are subdivided into antimicrobials, anti-darking and antioxidants (Carocho et al., 2014). These additives are used to extend the shelf life of food and ensure its safety. The main foods in which

"The Technological University of the Mixteca provided support.

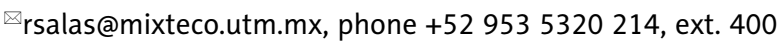


antioxidants are used are meats, oils, fried foods, seasonings, and dairy products, baked goods and extruded snacks (Baines and Seal, 2012).

\section{PRESERVATIVES}

All food raw materials have biochemical processes and are susceptible to attack by microorganisms, which modify their sensory properties and can produce toxic substances. Fats, oils, flavoring substances, vitamins and colors spontaneously oxidize when exposed to air, and the antioxidants protect against this oxidation (Amorati et al., 2013). There are a number of the factors that contribute to food oxidation, including the presence of oxygen, transition metals, moisture, heat and light. Oxygen and transition metals should be removed or sequestered to prevent, minimize or slow down the oxidation rate of food. Antioxidants are compounds that inhibit or retard the oxidative process, reducing changes in the taste, color and nutritive value of food (Shahidi and Zhong, 2010). The natural antioxidants used in food are ascorbic acid, carotenoids, phenolic compounds and tocopherols (Choe and Min, 2009).

\section{ANTIOXIDANTS}

The term antioxidant is associated with the effect of an antioxidant on a specific medium dependent of factors such as chemical reactivity, location at cellular level, concentration, mobility, interactions with free radicals, absorption, distribution, metabolism and excretion. Antioxidants are classified according to their mode of action, source or solubility (Gutteridge and Halliwell, 1994; Vertuani et al., 2004). According to their mode of action, antioxidants are grouped into five types: radical scavenging antioxidants or antioxidants that break the chain of radical propagation; chelators, which form complexes with metals and prevent them from initiating the formation of radicals; extinguishers, which deactivate high-energy oxidant species; oxygen scavengers, which remove oxygen from the systems, preventing their destabilization; and finally, regenerators of antioxidants, which reconstitute other antioxidants present in the food when they become radicals.

The deterioration rate of a food can be influenced by the presence of endogenous antioxidants, the presence of oxygen and toxic substances susceptible to oxidation, temperature, $\mathrm{pH}$ and light. Oxidation can be avoided or retarded by various media, for example by replacing air with inert gases during packaging, using enzymes that consume the oxygen present in the medium, incorporating UV radiation-absorbing substances into packaging and using cooling systems. These media are sometimes not sufficient to prolong the shelf life of some foods. For this reason, the use of exogenous antioxidants in food has become essential to retard oxidative deterioration and prolong its useful life. Antioxidants have specific properties and are more effective in some applications than others (Saltmarsh, 2013). A combination of two or more antioxidants is more effective than individual use, thus favoring the synergistic effects that enhance the activity of antioxidants. The use of antioxidant extracts can be very effective in food preservation.

Natural antioxidants have beneficial effects against neurodegenerative diseases induced by oxidative stress. Phenolic compounds are the most important group of natural antioxidant compounds, because they have strong antioxidant activity and important beneficial effects on human health. Among the most important effects are anticancer and antidiabetic activities. These compounds also help prevent cardiovascular, brain diseases and regulate the immune system (Carocho and Ferreira, 2013).

Below is a description of the natural sources of antioxidants that are used or are potential additive antioxidants.

\section{ANTIOXIDANTS FROM BERRY FRUITS}

Blueberries, strawberries, blackberries and others are characterized by high anthocyanin concentrations, a subgroup of phenolic compounds. Anthocyanins are water-soluble natural pigments with strong antioxidant activity used to inhibit lipid oxidation in food. Anthocyanins play an important role in the prevention and treatment of cardiovascular, neurodegenerative and cancer diseases (de Pascual-Teresa, 2014; Zafra-Stone et al., 2007). Tremblay et al. (2013) fed rats on a diet rich in cranberry fruits for 7 or 2 weeks and the results revealed reduced damage of light-induced injury to the retina. The blackcurrants are rich in anthocyanin and are used for treating diseases in Asia and Europe. 


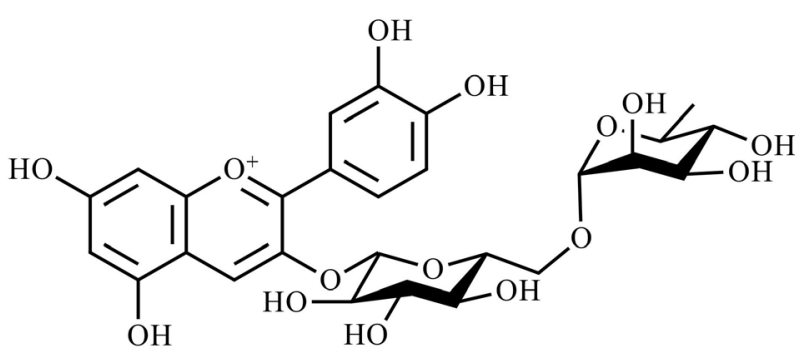

Fig. 1. Chemical structure of cyanidin-3-O-rutinoside

Bishayee et al. (2010) demonstrated that cyanidin-3-O-rutinoside (Fig. 1), an anthocyanin present in the extract of black gooseberry, could inhibit the growth of liver cancer HepG2 cells.

\section{ROSEMARY}

Rosemary (Rosmarinus officinalis L.) is a shrub very popular in Europe, because it is used as a herb for its pleasant flavor and aroma. This aroma is due to the presence of essential oils that represent between 1 and $3 \%$ of the total mass of leaves and flowers. The oil consists mainly of 1,8-cineol, $\alpha$-pinene and camphor. Rosemary has antioxidant activity due to the phenolic compounds found mainly in flowers. Among the phenolic compounds found in rosemary are carnosol, carnosic acid and rosmarinic acid. The rosemary extract has been approved as a food additive for use in the European Union since 2008 and is formally labeled "Extracts of Rosemary E392". The European Union Regulatory Commission no. 231/2012 notes that carnosol and carnosic acid (Fig. 2) are the reference

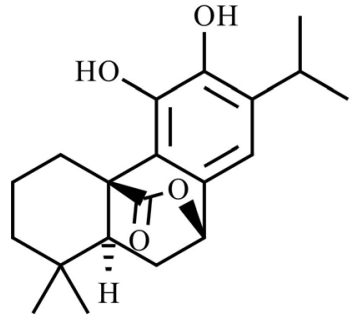

Carnosol<smiles>CC(C)c1cc2c(c(O)c1O)[C@@]1(O)CCCC(C)(C)[C@]1(O)CC2</smiles>

Carnosic acid
Fig. 2. Chemical structure of two major diterpene phenolics from rosemary extracts antioxidant compounds in rosemary extracts and the sum of these should not be less than $90 \%$ of the total phenolic diterpenes in the extract (de Raadt et al., 2015). Rosemary extracts also contain flavonoids with structures of luteolin and apigenin. Rosemary extracts are used as an additive to preserve meat, fish and oils (de Raadt et al., 2015).

A study of rosemary extract supplementation at carnoside acid and carnosol concentrations of 200 and $400 \mathrm{mg} \cdot \mathrm{kg}^{-1}$ were also carried out on lambs during the fattening stage (Ortuño et al., 2014). The results of this study showed that the half-life of the meat obtained from the lambs was prolonged.

A study carried out by Jordán et al. (2014) showed that the presence of carnosol in rosemary extracts is important for improving the oxidative stability of carnosic acid during the processing of sheep's tissue, enhancing the antioxidant activity of the rosemary extract. This shows that combining phenolic compounds with a similar chemical structure produces a synergistic effect in terms of their antioxidant activity.

Jensen et al. (2011) evaluated the sensory properties of rosemary extracts in the preparation of bread, and their results showed that the extract did not induce changes in the flavour and aroma of the product.

\section{TURMERIC}

Turmeric (Curcuma longa) is a plant with very branched rhizomes adapted to warm humid areas. The rhizomes of the plant are yellow and are used as a yellow dye and as a spice. Its spicy taste and golden color improves the quality of the food. Turmeric is also the main ingredient in curry powders, and has been used to accentuate the flavor of pepper. India is one of the largest producers of turmeric.

Turmeric is considered safe in amounts that are commonly used in food. The FDA declared this food a GRAS, which means that it is generally recognized as safe to use as a food additive. It is a versatile spice that helps detoxify the liver, balance cholesterol levels, fight allergies, stimulate digestion and increased immunity (Chainani, 2003). This plant contains the phenolic compound curcumin (diferuloylmethane). Curcumin has antioxidant, anticancer, antidiabetic, antiproliferative and antiangiogenic activity (Strimpakos and Sharma, 2008). The other two phenolic 


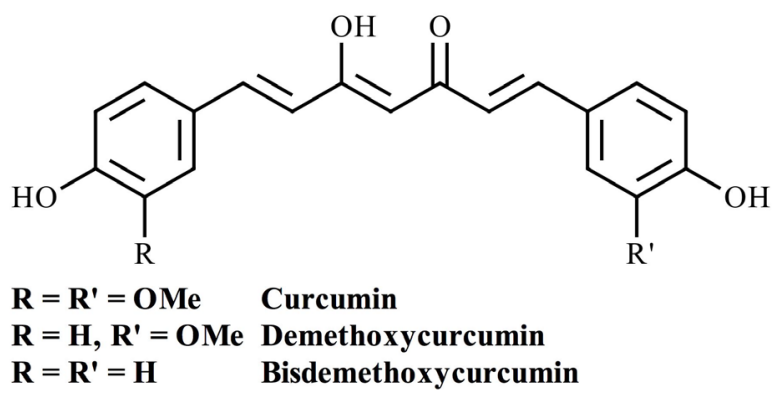

Fig. 3. Chemical structure of the main phenolic compounds from turmeric

compounds abundant in turmeric are demethoxycurcumin and bisdemethoxycurcumin, as shown in Figure 3. Curcumin provides turmeric with its yellow color and is now recognized as the compound responsible for most of its therapeutic effects. It is estimated that $2-5 \%$ of turmeric is curcumin. Curcuminoids decrease lipid peroxidation through conserving the activity of the antioxidant enzymes superoxide dismutase, catalase and glutathione peroxidase at high levels. The antioxidant properties of turmeric extracts are mainly due to diacetylcurcumin, demethoxycurcumin and bisdemethoxycurcumin (Faizal et al., 2009).

Curcumin has anticancer activity due to its effect on a variety of biological pathways involved in the mutagenesis, oncogene expression, cell cycle regulation, apoptosis, tumorigenesis, and metastasis (Wilken et al., 2011). Curcumin has an antiproliferative effect on various cancers and is an inhibitor of the NF-B transcription factor.

Turmeric powder (Curcuma longa) was used in a fried rice snack, yukwa, at different concentrations. The textural properties of yukwa were not changed until the turmeric powder content reached $5 \%$; however, an addition of over $8 \%$ induced a decrease in hardness and an increase in crispiness. Based on the sensory characteristics, a $5 \%$ addition of turmeric powder was the most acceptable for the yukwa product (Seugn-Taik and Han, 2016).

\section{SAFFRON}

Saffron (Crocus sativus L.) originates from Asia Minor and Iran, and is used as a spice in bakery products and beverages at concentrations of $260 \mu \mathrm{g} \cdot \mathrm{mL}^{-1}$ due to its taste and color (Selim et al., 2000). Several studies have demonstrated the pharmacological effects of saffron, including antioxidant, anti-tumor, anti-inflammatory and auxiliary activity in the treatment of liver disorders (Amin et al., 2011; Sanchez-Vioque et al., 2012). These properties have been attributed to the stigmas, the only commercially valuable part of the plant. The pyrogallol and gallic acid, phenolic compounds were isolated from saffron stigma (Fig. 4). The saffron stigma is a source of phenolic antioxidants, $654 \pm 2 \mathrm{mg}$ Gallic Acid Equivalent (GAE) $\times(100 \mathrm{~g}$ dry weight $)^{-1}$, which could improve food quality (Karimi et al., 2010).

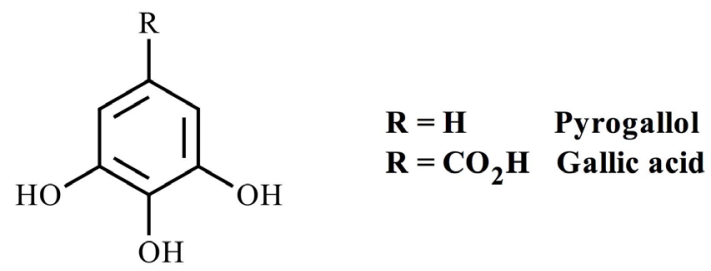

Fig. 4. Phenolic compound levels in saffron stigma

Saffron is used as additive in traditional fish and seafood dishes in Italy, France, Germany and Spain (Winterhalter and Straubinger, 2000). Sensory studies revealed the presence of 25 aroma-active compounds, and among these compounds is saffranal with a high flavor dilution factor (Winterhalter and Straubinger, 2000).

\section{GINGER}

Ginger (Zingiber officinale Rosc.) belongs to the Zingiberaceae family and is native to South-East Asia. Ginger is used in many countries as a spice and condiment to give a pungent taste to food (Park and Pizzuto, 2002). Ginger rhizome has also been used in traditional medicine, because of its diversity in terms of phytochemicals (Shukla and Singh, 2007). Jolad et al. (2004) grouped the phytochemicals of fresh ginger into volatiles and non-volatiles. Volatile compounds include sesquiterpenes and monoterpenoid hydrocarbons, which produce the aroma and flavor characteristics of ginger. Non-volatile compounds include 
<smiles>COc1cc(CCC(=O)C[C@@H](O)C(C)(C)C#N)ccc1O</smiles>

Gingerols<smiles>COc1cc(CCC(=O)CCC(C)(C)C)ccc1O</smiles>

Paradols<smiles>COc1cc(CCC(=O)/C=C/C=[W][V])ccc1O</smiles>

Shogaols<smiles>COc1cc(CCC(C)=O)ccc1O</smiles>

Zingerone

Fig. 5. Chemical structure of phenolic compounds from ginger root

gingerols, shogaols, paradols and zingerones, which give ginger its pungent taste, as shown in Figure 5. These non-volatiles compounds are free radical scavengers. El-Ghorab et al. (2010) reported a total of 570 mg GAE $\times(100 \text { g dry weight })^{-1}$.

Ginger and its phenolic compounds are dual inhibitors of arachidonic acid metabolism. This means that phenolic compounds inhibit both cyclooxygenase and lipoxygenase, enzymes involved in the biosynthetic pathway of prostaglandin and leukotriene (Moghaddasi and Kashani, 2012). Müller et al. (2006) showed that ginger is more effective than indomethacin in reducing pain associated with inflammation and oxidative stress. In addition, ginger may decrease muscle pain caused by strenuous exercise (Black et al., 2010).

Recently, Simon-Brown et al. (2016) developed a method of microencapsulation for ginger extracts using spray-drying technology. This allowed significant quantities of phenolic compounds to be retained in powders. Phenolic compounds in microencapsulated ginger can be incorporated quickly into products such as tea and bread.

On the other hand, Kisnk and Elsheshetawy (2013) used ginger powder as an additive in mayonnaise and the sensory attributes enhanced as a function of the ginger at concentrations of 1.0 and $1.25 \%$.

\section{CHILLI}

Chilli is one of the spices most consumed in the world and usually is used as a food additive (Bown, 2001). This fruit is part of the traditional medicine of India, Mexico and China, and is used for the treatment of arthritis, rheumatism and upset stomach (Van Wyk and Wink, 2004). These applications are related to capsaicinoids, phenolic compounds representative of the Capsicum genus (Zimmer et al., 2012), as well as to flavonoids and phenylpropanoids (Materska, 2014). The capsaicinoids are $N$-vanillylamides derived from fatty acids with 9-11 carbons, and the compounds most abundant are capsaicin (8-methylnontrans-6-enoic acid vanillylamide) and dihydrocapsaicin (8-methylnonanoic acid vanillylamide), as shown in Figure 6. The sum of both compounds occurs in the chilli fruit in quantities greater than $80 \%$ with respect to the total capsaicins (Topuz and Özdemir, 2007). The capsaicinoid concentration varies significantly from cultivar to cultivar. Wahyuni et al. (2011) studied 32 different cultivars of Capsicum and found that the cultivar of C. frutescens Lombok (No. 28) contained the highest concentrations of capsaicinoids in the pericarp, with levels of capsaicin and dihydrocapsaicin of 60 and $15 \mathrm{mg} \times(100 \mathrm{~g} \text { of fresh weight })^{-1}$, respectively. 
<smiles>COc1cc(CNC(=O)CCCC/C=C/C(C)C)ccc1O</smiles>

Capsaicin<smiles>COc1cc(CNC(=O)CCCCCCC(C)C)ccc1O</smiles>

Dihydrocapsaicin

Fig. 6. Chemical structure of capsaicin and dihydrocapsaicin from genus Capsicum

Conforti et al. (2007) evaluated the antioxidant activity of the methanol extract of the hot pepper fruit (C. annuиm L. var. acuminatum) at three stages of maturation (small green, green and red), the free radicalscavenging activity was measured using 2,2-diphenyl-1-picrylhydrazyl radical ( $\mathrm{DPPH}^{\cdot}$ ) assay, bovine brain peroxidation assay and $\beta$-carotene bleaching test. The variation in lipophilic and phenol compounds shown in the three stages of maturation of the fruits of C. annuum generated differences in antioxidant activity. The green pepper extracts showed significant activity to avoid lipid peroxidation, with the subsequent inhibiting the formation of malondialdehyde (MDA), while the small green pepper showed greater free radicalscavenging activity.
On the other hand, it should be noted that in addition to the capsaicins, phenylpropanoids and flavonoids have also been identified in chilli fruit. Materska (2014) carried out a study to identify phenolic compounds in the fruits of sweet (Red Knight, Shanghai and Socrates varieties) and semi-spicy (Capel Hot variety) chillis. The flavonoids identified in these cultivars were glycosides of flavonoids derived from quercetin, luteolin, and apigenin.

The chilli has been used to prevent degradative processes of oils and fruits; for example, Martínez-Tomé et al. (2001) showed C. annuum extracts are capable of inducing significant oxidative stability in refined olive oil tested using the Rancimat method. On the other hand, Ponce et al. (2008) used a chitosan coating enriched with chilli oleoresin for the antioxidant protection of minimally processed butternut squash, inducing the prevention of browning reactions.

\section{GREEN TEA}

The antioxidant properties of green tea are due to the presence (Fig. 7; Higdon and Frei, 2003; Zandi and Gordon, 1999) of catechin, epicatechin (EC), epicatechin gallate (ECG), epigallocatechin (EGC), epigallocatechin gallate (EGCG). Green tea catechins have free radical scavenging and metal chelating activities. Therefore, green tea extracts are used as natural antioxidant additives in food (Manzocco et al., 1998).

The tea catechins have been used in the conservation of beef, pork and poultry meat (McCarthy et al., 2001, Tang et al., 2001; Mitsumoto et al., 2005; Nissen et al.,

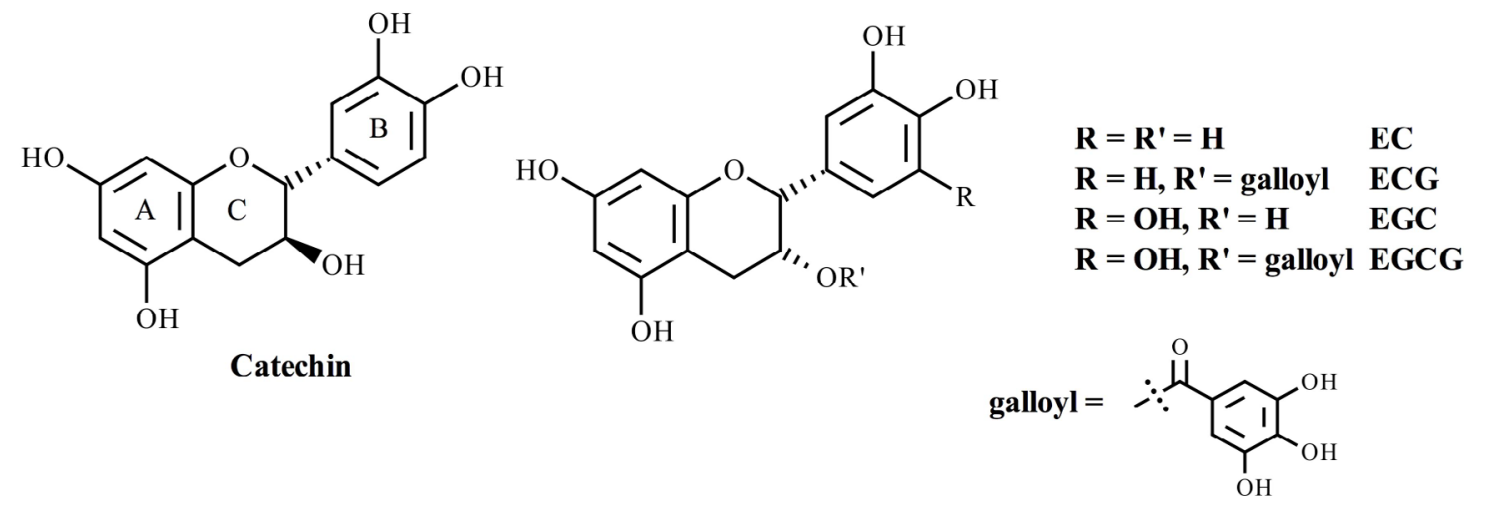

Fig. 7. Chemical estructure of catechins from tea leaves 
2004). On the other hand, Jamwal et al. (2015) evaluated the effect of green tea extract on the quality parameters of chicken patty storage. Green tea extract was added at concentrations of $400 \mathrm{mg} \cdot \mathrm{kg}^{-1}$ to the products and the chicken patties were re-packaged under conditions of refrigeration $\left(4 \pm 1^{\circ} \mathrm{C}\right)$ for 21 days. The results of this study show green tea extract reduced almost all the parameters of oxidation evaluated in the study.

Jongberg et al. (2013) showed that green tea extract reduces oxidation of lipids and the level of formation of carbonyls in bologna-type sausage made with pork meat, prepared under oxidative stress; however, the loss of thiol and protein crosslink (indicators of proteins oxidation) did not diminish.

Ahmad et al. (2015) added green tea extract at different levels $(1,2$ and $4 \%)$ to wheat flour to make cookies. Sensory analysis revealed that the addition of $4 \%$ green tea extract to wheat flour increased the acceptability of color, aroma and taste. In another study, Najgebauer-Lejko (2014) evaluated the effect of green tea as an additive in probiotic milks (bioyogurts). The results of this study show green tea could be successfully used as an additive for probiotic milks, enhancing their health benefits without significant differences between the sensory notes received for bioyogurts.

\section{SOY}

Soy (Glycine max) is cultivated from its seeds, and oil and flour rich in protein is obtained from this product. Soybeans also contain isoflavones (Fig. 8), phenolic compounds that have antioxidant activity and

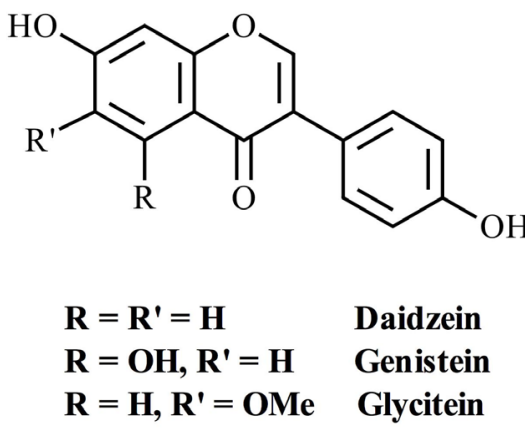

Fig. 8. Chemical estructure of isoflavones from soybeans can prevent ovarian, cervical, and breast cancers. Lee et al. (2014) observed that the intake of soy foods in patients with ovarian cancer was lower $(75.3 \pm 53.6$ $\mathrm{g} \cdot$ day $\left.^{-1}\right)$ than the control group $\left(110.7 \pm 88.8 \mathrm{~g} \cdot \mathrm{day}^{-1}\right)$. The protective effect of soybean and isoflavones is supported by experimental evidence. Ovarian cancer is an estrogen-dependent cancer. Isoflavones induce apoptosis and inhibit the growth and proliferation of ovarian cancer cells (Chen and Anderson, 2001). These compounds are structurally related to the endogenous estrogen and stimulate the production of sex hormone binding in the liver, which in turn causes levels of bioavailable estrogen to decrease (Adlercreutz et al., 1987). Another acceptable mechanism is inhibition of ovarian aromatase activity, an enzyme that converts androgens into estrogens, as was shown by an in vitro study (Pelissero et al., 1996). Polar extracts of soybeans rich in isoflavones can be used as a food additive for women.

\section{SARSAPARILLA}

Sarsaparilla is a group of approximately 350 species of the genus Smilax (Smilacaceae) and is characteristic for being climbing shrubs with a long and thin thorny trunk. The roots of these plants have been used to prepare a beverage, sarsaparilla, which has antioxidant properties. These properties are attributed to phenolic compounds, including flavonoids and phenylpropanoid glycosides with a sucrose base fragment. SalasCoronado et al. (2017) analyzed the nature of the phenols and their properties in a group of Smilax species. The sarsaparilla root is a rich source of phenolic compounds and, according the FDA, is considered a food material generally recognized as safe (GRAS). Therefore, root extracts of sarsaparilla can be used as an antioxidant additive for food.

\section{CONCLUSIONS}

The use of natural additives is steadily increasing because consumers associate synthetic additives with diseases. Antioxidant additives are used because they prolong the life of a food, and it is becoming more common to use extracts of plants rich in phenolic compounds. However, before using them it is very important to know their chemical composition and the biological 
Santos-Sánchez, N. F., Salas-Coronado, R., Valadez-Blanco, R., Hernández-Carlos, B., Guadarrama-Mendoza, P. C. (2017). Natural antioxidant extracts as food preservatives. Acta Sci. Pol. Technol. Aliment., 16(4), 361-370. http://dx.doi.org/10.17306/J. AFS.2017.0530

properties of these extracts. Phenolic compounds, in addition to presenting antioxidant activity, have been associated with properties such as anticancer, antidiabetic, antimicrobial, etc. Antioxidant extracts are associated with products aimed at groups of consumers that are seeking to preserve or improve their health.

\section{ACKNOWLEDGMENTS}

The authors thank Carol Ann Hayenga for her English assistance in the preparation of this manuscript.

\section{REFERENCES}

Adlercreutz, H., Höckerstedt, K., Bannwart, C., Bloigu, S., Hämäläinen, E., Fotsis, T., Ollus, A. (1987). Effect of dietary components, including lignans and phytoestrogens, on enterohepatic circulation and liver metabolism of estrogens and on sex hormone binding globulin (SHBG). J. Steroid Biochem., 27, 1135-44. https://doi. org/10.1016/0022-4731(87)90200-7

Ahmad, M., Baba, W. N., Wani, T. A., Gani, A., Gani, A., Shah, U., ..., Masoodi, F. A. (2015). Effect of green tea powder on thermal, rheological and functional properties of wheat flour and physical, nutraceutical and sensory analysis of cookies. J. Food Sci. Technol., 52(9), 57995807. http://dx.doi.org/10.1007/s13197-014-1701-3

Amin, A., Hamza, A. A., Bajbouj, K., Ashraf, S. S., Daoud, S. (2011). Saffron: A potential candidate for a novel anticancer drug against hepatocellular carcinoma. Hepatology, 54(3), 857-867. https://doi.org/10.1002/hep.24433

Amorati, R., Foti, M. C., Valgimigli, L. (2013). Antioxidant activity of essential oils. J. Agric. Food Chem., 61(46), 10835-10847. http://doi.org/10.1021/jf403496k

Baines, D., Seal, R. (2012). Natural food additives, ingredients and flavourings, Woodhead Publishing, Cambridge, UK.

Bishayee, A., Háznagy-Radnai, E., Mbimba, T., Sipos, P., Morazzoni, P., Darvesh, A. S., ..., Hohmann, J. (2010). Anthocyanin-rich black currant extract suppresses the growth of human hepatocellular carcinoma cells. Natural Prod. Commun., 5(10), 1613-1618.

Black, C. D., Herring, M. P., Hurley, D. J., O’Connor, P. J. (2010). Ginger (Zingiber officinale) reduces muscle pain caused by eccentric exercise. J. Pain, 11(9), 894-903. https://doi.org/10.1016/j.jpain.2009.12.013

Bown, D. (2001). New encyclopedia of herbs and their uses. London, UK: Dorling Kindersley, London, Herb Society of America.

Carocho, M., Barreiro, M. F., Morales, P., Ferreira, I. C. F. R. (2014). Adding molecules to Food, pros and cons:
A review of synthetic and natural food additives. Compr. Rev. Food Sci. Food Safety, 13(4), 377-399. https://doi. org/10.1111/1541-4337.12065

Carocho, M., Ferreira, I. C. F. R. (2013). The role of phenolic compounds in the fight against cáncer - a review. AntiCancer Agents Med. Chem., 13(8), 1236-1258. PMID: 23796249.

Chainani-Wu, N. (2003). Safety and anti-inflammatory activity of curcumin: A component of tumeric (Curcuma longa). J. Altern. Compl. Med., 9(1), 161-168. https:// doi.org/10.1089/107555303321223035

Chen, X., Anderson, J. J. B. (2001). Isoflavones inhibit proliferation of ovarian cancer cells in vitro via an estrogen receptor-dependent pathway. Nutr. Cancer, 41(1-2), 165-171. https://doi.org/10.1080/01635581.2001.96806 28

Choe, E., Min, D. B. (2009). Mechanisms of antioxidants in the oxidation of foods. Compr. Rev. Food Sci. Food Safety, 8(4), 345-358. http://dx.doi.org/10.1111/j.1541-4337. 2009.00085.x

Conforti, F., Statti, G. A., Menichini, F. (2007). Chemical and biological variability of hot pepper fruits (Capsicum annuum var. acuminatum L.) in relation to maturity stage. Food Chem., 102(4), 1096-1104. https://doi. org/10.1016/j.foodchem.2006.06.047

de Pascual-Teresa, S. (2014). Molecular mechanisms involved in the cardiovascular and neuroprotective effects of anthocyanins. Arch. Biochem. Biophys., 559, 68-74. https://doi.org/10.1016/j.abb.2014.04.012

de Raadt, P., Wirtz, S., Vos, E., Verhagen, H. (2015). Short review of extracts of Rosemary as a food additive. Eur. J. Nutr. Food Safety, 5(3), 126-137. https://doi. org/10.9734/EJNFS/2015/10404

El-Ghorab, A. H., Nauman, M., Anjum, F. M., Hussain, S., Nadeem, M. (2010). A comparative study on chemical composition and antioxidant activity of ginger (Zingiber officinale) and cumin (Cuminum cyminum). J. Agric. Food Chem., 58(14), 8231-8237. https://doi. org/10.1021/jf101202x

Faizal, P., Kumar, R. S., Augusti, K. T. (2009). A study on the hypoglycemic and hypolipidemic effects of an ayurvedic drug Rajanyamalakadi in diabetic pacients. Indian J. Clin. Biochem., 24(1), 82-87. https://doi.org/10.1007/ s12291-009-0014-1

Gutteridge, J. M. C., Halliwell, B. (1994). Antioxidants in nutrition, health and disease. Oxford, UK: Oxford University Press.

Higdon, J. V., Frei, B. (2003). Tea catechins and polyphenols: Health effects, metabolism, and antioxidant functions. Critic. Rev. Food Sci. Nutr., 43(1), 89-143. https://doi.org/10.1080/10408690390826464 
Santos-Sánchez, N. F., Salas-Coronado, R., Valadez-Blanco, R., Hernández-Carlos, B., Guadarrama-Mendoza, P. C. (2017). Natural antioxidant extracts as food preservatives. Acta Sci. Pol. Technol. Aliment., 16(4), 361-370. http://dx.doi.org/10.17306/J. AFS.2017.0530

Jamwal, A., Kumar, S., Bhat, Z. F., Kumar, A., Kaur, S. (2015). The quality and storage stability of chicken patties prepared with different additives. Nutr. Food Sci., 45(5), 728-739. https://doi.org/10.1108/ NFS-01-2015-0009

Jensen, S., Ostdal, H., Skibsted, L. H., Thybo, A. K. (2011). Antioxidants and shelf life of whoe wheat bread. J. Cereal Sci., 53, 291-297. https://doi.org/10.1016/j. jcs.2011.01.010

Jiang, H., Xie, Z., Koo, H. J., McLaughlin, S.P., Timmermann, B. N., Gang, D. R. (2006). Metabolic profiling and phylogenetic analysis of medicinal Zingiber species: Tools for authentication of ginger (Zingiber officinale Rosc.). Phytochemistry, 67, (15), 1673-1685. https://doi.org/10.1016/j.phytochem.2005.08.001

Jolad, S. D., Lantz, R. C., Solyom, A. M., Chen, G. J., Bates, R. B., Timmermann, B. N. (2004). Fresh organically grown ginger (Zingiber officinale): composition and effects on LPS-induced $\mathrm{PGE}_{2}$ production. Phytochemistry, 65(13), 1937-1954. https://doi.org/10.1016/j. phytochem.2004.06.008

Jongberg, S., Tørngren, M. A., Gunvig, A., Skibsted, L. H., Lund, M. N. (2013). Effect of green tea or rosemary extract on protein oxidation in Bologna type sausages prepared from oxidatively stressed pork. Meat Sci., 93(3), 538-546. https://doi.org/10.1016/j.meatsci.2012.11.005

Jordán, M. J., Castillo, J., Bañón, S., Martínez-Conesa, C., Sotomayor, J. A. (2014). Relevance of the carnosic acid/carnosol ratio for the level of rosemary diterpene transfer and for improving lamb meat antioxidant status. Food Chem., 151, 212-218. https://doi.org/10.1016/j. foodchem.2013.11.068

Karimi, E., Oskoueian, E., Hendra, R., Jaafar, H. Z. E. (2010). Evaluation of Crocus sativus L. stigma phenolic and flavonoid compounds and its antioxidant activity. Molecules, 15(9), 6244-6256. https://doi.org/10.3390/ molecules 15096244

Kisnk, Y. F. M., Elsheshetawy, H. E. (2013). Effect of ginger powder on the mayonnaise oxidative stability, rheological measurements, and sensory characteristics. Ann. Agric. Sci., 58, 213-220. http://dx.doi.org/10.1016/j. aoas.2013.07.016

Lee, A. H., Su, D., Pasalich, M., Tang, L., Binns, C. W., Qiu, L. (2014): Soy and isoflavone intake associated with reduced risk of ovarian cancer in southern Chinese women. Nutr. Res., 34(4), 302-307. https://doi.org/10.1016/j. nutres.2014.02.005

Manzocco, L., Anese, M., Nicoli, M. C. (1998). Antioxidant properties of tea extracts as affected by processing. LWT - Food Sci. Technol., 31(7-8), 694-698. https:// doi.org/10.1006/fstl.1998.0491
Martínez-Tomé, M., Jiménez, A. M., Ruggieri, S., Frega, N., Strabbioli, R., Murcia, M. A. (2001). Antioxidant properties of mediterranean spices compared with common food additives. J. Food Prot., 64(9), 1412-1419. https:// doi.org/10.4315/0362-028X-64.9.1412

Materska, M. (2014). Bioactive phenolics of fresh and freeze-dried sweet and semi-spicy pepper fruits (Capsicum annuum L.). J. Funct. Foods, 7, 269-277. https:// doi.org/10.1016/j.jff.2014.02.002

McCarthy, T. L., Kerry, J. P., Kerry, J. F., Lynch, P. B., Buckley, D. J. (2001). Evaluation of the antioxidant potential of natural food/plant extracts as compared with synthetic antioxidants and vitamin $\mathrm{E}$ in raw and cooked pork patties. Meat Sci., 57(1), 45-52. https://doi.org/10.1016/ S0309-1740(00)00129-7

Mitsumoto, M., O’Grady, M. N., Kerry, J. P., Buckley, D. J. (2005). Addition of tea catechins and vitamin C on sensory evaluation, colour and lipid stability during chilled storage in cooked or raw beef and chicken patties. Meat Sci., 69(4), 773-779. https://doi.org/10.1016/j. meatsci.2004.11.010

Moghaddasi, M. S., Kashani, H. H. (2012). Ginger (Zingiber officinale): A review. J. Med. Plants Res., 6(26), 4255-4258.

Morouti, N., Panagiotakus, D. B. (2013). Soy food consumption and breast cancer. Maturitas, 76(2), 118-122. https://doi.org/10.1016/j.maturitas.2013.07.006

Müller, W., Fiebich, B. L., Stratz, T. (2006). New treatment options using 5-HT3 receptor antagonists in rheumatic diseases. Curr. Topics Med. Chem., 6(18), 2035-2042. https://doi.org/10.2174/156802606778522122

Najgebauer-Lejko, D. (2014). Effect of green tea supplementation on the microbiological, antioxidant, and sensory properties of probiotic milks. Dairy Sci. Technol., 94(4), 327-339. https://doi.org/10.1007/s13594-014-0165-6

Nissen, L. R., Byrne, D. V., Bertelsen, G., Skibsted, L. H. (2004). The antioxidative activity of plant extracts in cooked pork patties as evaluated by descriptive sensory profiling and chemical analysis. Meat Sci., 68, 485-495. https://doi.org/10.1016/j.meatsci.2004.05.004

Ortuño, J., Serrano, R., Jordán, M. J., Bañón, S. (2014). Shelf life of meat from lambs given essential oil-free rosemary extract containing carnosic acid plus carnosol at 200 or $400 \mathrm{mg} \mathrm{kg}^{-1}$. Meat Sci., 96, 1452-1459. https:// doi.org/10.1016/j.meatsci.2013.11.021

Park, E. J., Pizzuto, J. M. (2002). Botanicals in cancer chemoprevention. Cancer Metast. Rev., 21(3-4), 231-255.

Pelissero, C., Lenczowski, M. J., Chinzi, D., Davail-Cuisset, B., Sumpter, J. P., Fostier, A. (1996). Effects of flavonoids on aromatase activity, an in vitro study. J. Steroid 
Santos-Sánchez, N. F., Salas-Coronado, R., Valadez-Blanco, R., Hernández-Carlos, B., Guadarrama-Mendoza, P. C. (2017). Natural antioxidant extracts as food preservatives. Acta Sci. Pol. Technol. Aliment., 16(4), 361-370. http://dx.doi.org/10.17306/J. AFS.2017.0530

Biochem. Molec. Biol., 57(3-4), 215-23. https://doi. org/10.1016/0960-0760(95)00261-8

Ponce, A. G., Roura, S. I., del Valle, C. E., Moreira, M. R. (2008). Antimicrobial and antioxidant activities of edible coatings enriched with natural plant extracts: In vitro and in vivo studies. Postharv. Biol. Technol., 49, 294 300. https://doi.org/10.1016/j.postharvbio.2008.02.013

Salas-Coronado, R., Hernández-Carlos, B., Llaguno-Guilberto, J., Santos-Sánchez, N. F. (2017). Phenolic compounds in genus Smilax (Sarsaparilla). In M. Soto-Hernandez, M. Palma-Tenango, M. del Rosario Garcia-Mateos (Eds.), Phenolic compounds - natural sources. Importance and applications. InTech. Available from: http://www.intechopen.com/books/phenolic-compounds-natural-sources-importance-and-applications/ phenolic-compounds-in-genus-smilax-sarsaparilla-

Saltmarsh, M. (2013). Essential guide to food additives ( $4^{\text {th }}$ ed). Cambridge, UK: RSC Publ.

Sanchez-Vioque, R., Rodrigues-Conde, M. F., Reina-Urena, J. V., Escolano-Tercero, M. A., Herraiz-Penalver, D., Santana-Meridas, O. (2012). In vitro antioxidant and metal chelating properties of corm, petal and leaf from saffron (Crocus sativus L.). Ind. Crops Prod., 39, 149153. https://doi.org/10.1016/j.indcrop.2012.02.028

Selim, K., Tsimidou, M., Biliaderis, C. G. (2000). Kinetic studies of degradation of saffron carotenoids encapsulated in amorphous polymer matrices. Food Chem., 71(2), 199206. https://doi.org/10.1016/S0308-8146(00)00156-4

Seugn-Taik, L., Han, J. H. (2016). Improvement in antioxidant functionality and shelf life of yukwa (fried rice snack) by turmeric (Curcuma longa L.) powder addition. Food Chem., 199, 590-596. http://dx.doi.org/10.1016/j. foodchem.2015.12.046

Shahidi, F., Zhong, Y.(2010). Novel antioxidants in food preservation and health promotion. Eur. J. Lipid Sci. Technol., 112(9), 930-940. http://doi.org/10.1002/ejlt.20100 0044

Shukla, Y., Singh, M. (2007). Cancer preventive properties of ginger: A brief review. Food Chem. Toxicol., 45(5), 683-690. https://doi.org/10.1016/j.fct.2006.11.002

Simon-Brown, K., Solval, K. M., Chotiko, A., Alfaro, L., Reyes, V., Liu, C., ..., Sathivel, S. (2016). Microencapsulation of ginger (Zingiber officinale) extract by spray drying technology. LWT - Food Sci. Technol., 70, 119125. https://doi.org/10.1016/j.lwt.2016.02.030

Strimpakos, A. S., Sharma, R. A. (2008). Curcumin: preventive and therapeutic properties in laboratory studies and clinical trials. Antioxid. Redox Signal., 10(3), 511-545. https://doi.org/10.1089/ars.2007.1769

Tang, S. Z., Kerry, J. P., Sheehan, D., Buckley, D. J. (2001). A comparative study of tea catechins and $\alpha$-tocopherol as antioxidants in cooked beef and chicken meat. Eur. Food Res. Technol., 213(4), 286-289. https://doi.org/10.1007/ s002170100311

Topuz, A., Ozdemir, F. (2007). Assessment of carotenoids, capsaicinoids and ascorbic acid composition of some selected pepper cultivars (Capsicum annum L.) grown in Turkey. J. Food Comp. Anal., 20, 596-602. https://doi. org/10.1016/j.jfca.2007.03.007

Tremblay, F., Waterhouse, J., Nason, J., Kalt, W. (2013). Prophylactic neuroprotection by blueberry-enriched diet in a rat model of light-induced retinopathy. J. Nutr. Biochem., 24(4), 647-655. https://doi.org/10.1016/j. jnutbio.2012.03.011

Van Wyk B.-E., Wink, M. (2004). Medicinal plants of the world: An illustrated scientific guide to important medicinal plants and their uses. Portland, Ore, USA: Timber Press.

Vertuani, S., Angusti, A., Manfredini, S. (2004). The antioxidants and pro-antioxidants network: An overview. Curr. Pharmac. Design, 10(14), 1677-1694. https://doi. org/10.2174/1381612043384655

Wahyuni, Y., Ballester, A.-R., Sudarmonowati, E., Bino, R. J., Bovy, A. G. (2011). Metabolite biodiversity in pepper (Capsicum) fruits of thirty-two diverse accessions: Variation in health-related compounds and implications for breeding. Pytochemistry, 72(11-12), 1358-1370. https://doi.org/10.1016/j.phytochem.2011.03.016

Wilken, R., Veena, M. S., Wang, M. B., Srivatsan, E. S. (2011). Curcumin: A review of anti-cancer properties and therapeutic activity inhead and neck squamous cell carcinoma. Mol. Cancer, 10(12), 1-19. http://dx.doi. org/10.1186/1476-4598-10-12

Winterhalter, P., Straubinger, M. (2000). Saffron - Renewed interest in an ancient spice. Food Rev. Int., 16(1), 39-59. http://dx.doi.org/10.1081/FRI-100100281

Zafra-Stone, S., Yasmin, T., Bagchi, M., Chatterjee, A., Vinson, J. A., Bagchi, D. (2007). Berry anthocyanins as novel antioxidants in human health and disease prevention. Mol. Nutr. Food Res., 51(6), 675-683. http://doi. org/10.1002/mnfr.200700002

Zandi, P., Gordon, M. H. (1999). Antioxidant activity of extracts from old tea leaves. Food Chem., 64(3), 285-288. https://doi.org/10.1016/S0308-8146(98)00047-8

Zimmer, A. R., Leonardi, B., Miron, D., Schapoval, E., Oliveira, J. R., Gosmann, G. (2012). Antioxidant and antiinflammatory properties of Capsicum baccatum: from traditional use to scientific approach. J. Ethnopharm., 139(1), 228-233. 